\title{
Youth Unemployment in Canada, 1976-1998
}

\author{
MORLEy Gunderson \\ Centre for Industrial Relations and Department of Economics \\ University of Toronto
}

ANDREW SHARPE

Centre for the Study of Living Standards, Ottawa

STEVEN WALD

Centre for Industrial Relations, University of Toronto

Une analyse du chômage chez les jeunes indique que: (I) Le ratio jeunes-adultes prend une forme de U dans le temps. Ce ratio diminue rapidement de 1976 à 1983, se stabilise entre 1984 et 1990 puis augmente rapidement par la suite, et ce principalement chez les adolescents. (II) Cette forme est le résultat de deux phénomènes: une amélioration relative chez les non-étudiants vers la fin des années 70 et 80 ainsi qu'une détérioration relative, durant les années 90, chez les étudiants à temps plein se cherchant du travail à temps partiel. (III) Sans la taille décroissante de la cohorte des jeunes, le ratio du chômage jeunes-adultes aurait été susbtantiellement plus élevé que son niveau déjà élevé des années 90. (IV) Les récessions tendent à créer une augmentation du chômage des jeunes relativement à celui des adultes et ce chez les hommes, non-étudiants, tandis qu'elles provoquent une diminution chez les étudiants. (V) Le marché du travail chez les jeunes est non-homogène mais varie considérablement entre les hommes et femmes, adolescents et jeunes adultes, et étudiants et non-étudiants.

Analysis of youth unemployment indicates: (i) The ratio of youth-adult rates exhibits a U-shaped pattern, declining markedly from 1976 to1983, levelling off from 1984 to 1990, but rising sharply thereafter, mainly for teenagers. (ii) The pattern results from the combination of a relative improvement among non-students in the late 1970s and 1980s, and a relative deterioration for full-time students seeking part-time work over the 1990s. (iii) If it were not for the declining youth cohort size, the ratio of youth to adult unemployment would have been substantially higher than its already high ratio in the 1990s. (iv) Recessions tend to worsen the unemployment of youths relative to adults for non-student males while improving it for students. (v) The youth labour market is not homogeneous, but varies considerably between males and females, teenagers and young adults, and students and non-students.

Morley Gunderson is the CIBC Professor of Youth Employment at the University of Toronto and Professor at the Centre for Industrial Relations and the Department of Economics. He is a Research Associate of the Institute for Policy Analysis, the Centre for International Studies, and the Institute for Human Development, Life Course and Aging at the University of Toronto, and an Adjunct Scientist at the Institute for Work and Health. During 1998/99, when this paper was written, he was a Visiting Fellow at the Hoover Institution at Stanford. Andrew Sharpe is the Executive Director of the Centre for the Study of Living Standards in Ottawa. Steven Wald is a PhD candidate at the Centre for Industrial Relations at the University of Toronto. 
$I^{-1}$ ssues associated with the unemployment of $\mathrm{Ca}$ nadian youth continue to attract policy attention. As documented subsequently, this reflects in part the fact that certain segments of the youth population - male and female teenagers - have attained record, or near record, unemployment rates well into the economic recovery after the recession of the early 1990s. While young adults (aged 20-24 years) did not face similar increases in their unemployment rates, they too experienced deteriorating positions (relative to adults) over the 1990s.

By most of the other main economic barometers, labour market outcomes for youth also worsened in the 1980s and especially the 1990s. These include:

- disproportionate declines in labour supply whether measured by hours worked (Wilkins 1998) or the labour force participation rate (Archambault and Grignon 1999; Jennings 1998);

- declining real hourly wages of young people with the declines also likely having permanent long-run effects on their life-cycle, age-earnings profiles (Picot 1998; Morissette 1998);

- a decline in the proportion of the youth population employed (Morissette 1998; Wilkins 1998);

- disproportionate increases in non-standard work arrangements such as part-time work and contract work (Betcherman and Leckie 1996; Marquardt 1996; Morissette 1998); and

- reductions in upward mobility of youths out of low-wage jobs (Morissette 1998).

Due in part to the above outcomes, and to the fact that postsecondary tuition has risen much faster than inflation or youth wages, today's youth are also facing skyrocketing debt loads. ${ }^{1}$ The economic plight of many young people is also reflected in the fact that many remain or return to live with their parents - home ownership or even renting being out of their means. The increase was especially noticeable for young adults; nearly 57 percent lived with their parents in 1996, up from 43 percent in 1981 (Statistics Canada 1999a; Meunier, Bernard and Boisjoly 1998).

The policy importance of the issue is highlighted by the fact that high rates of youth unemployment will make the already difficult transition from school to work even more difficult. Early bouts of involuntary unemployment can lead to permanent "scarring effects" if the initial negative experiences become self-fulfilling, sowing the seeds that can lead to longer run unemployment or even complete withdrawal from the labour force.

The policy importance of youth unemployment, however, may be mitigated somewhat by the fact that the youth of the 1990s belong to a relatively smaller cohort than did the youth of the recession of the early 1980s, when the peak of the baby boom was under 25 (Foot 1997). Furthermore, many of the unemployed youths are full-time students searching for part-time work. ${ }^{2}$ The hardship associated with their being unemployed may not be as great as it is for unemployed youths who are not in school or are in school part-time. Due, in part, to rising school enrolment rates, the fraction of unemployed youth who are students has been increasing steadily over the past 23 years. As indicated in Table 1, in 1976, 22.2 percent of the unemployed teenagers (15-19) were also full-time students, while in 1998, this had increased to 61.9 percent. Young adults (2024) experienced an even more dramatic increase; in 1976 only 2.4 percent of the unemployed were fulltime students, while in 1998 this had increased to 14.7 percent.

In terms of the fraction of time spent in unemployment, in 1994, 52.1 percent of the total weeks that teenagers spent in unemployment were attributable to full-time students, while for young adults, the corresponding figure is 20.3 percent (see Table 2). Present-day teenage unemployment, therefore, largely involves full-time students seeking 
TABLE 1

Full-Time Student Enrolment Rates and Share of Unemployment, Canada, 1976-1998

\begin{tabular}{lcccc}
\hline & \multicolumn{2}{c}{ Teenagers (15-19) } & \multicolumn{2}{c}{ Young Adults (20-24) } \\
Year & Enrolment Rate (\%) & \% of Unemployed & Enrolment Rate (\%) & \% of Unemployed \\
\hline & $(1)$ & $(2)$ & $(3)$ & $(4)$ \\
1976 & & 22.2 & 14.9 & 2.4 \\
1977 & 65.4 & 21.5 & 15.0 & 2.3 \\
1978 & 65.3 & 24.6 & 14.4 & 2.5 \\
1979 & 64.8 & 25.8 & 14.2 & 2.8 \\
1980 & 64.2 & 28.1 & 14.0 & 2.1 \\
1981 & 65.5 & 29.4 & 14.6 & 3.5 \\
1982 & 66.6 & 27.7 & 14.9 & 2.9 \\
1983 & 67.9 & 32.7 & 16.5 & 3.4 \\
1984 & 70.1 & 36.5 & 17.7 & 3.5 \\
1985 & 71.7 & 41.5 & 19.0 & 4.0 \\
1986 & 73.9 & 43.2 & 19.8 & 4.6 \\
1987 & 75.5 & 48.1 & 20.5 & 5.5 \\
1988 & 75.6 & 48.7 & 20.7 & 4.7 \\
1989 & 76.9 & 49.3 & 22.1 & 6.4 \\
1990 & 76.4 & 49.2 & 23.7 & 7.5 \\
1991 & 77.1 & 50.4 & 26.1 & 8.3 \\
1992 & 79.3 & 54.5 & 27.8 & 8.8 \\
1993 & 80.9 & 58.3 & 29.8 & 8.1 \\
1994 & 82.0 & 57.7 & 30.6 & 9.1 \\
1995 & 81.6 & 54.1 & 31.9 & 10.9 \\
1996 & 81.0 & 56.4 & 32.6 & 15.4 \\
1997 & 80.7 & 63.6 & 34.3 & 14.7 \\
1998 & 82.3 & 61.9 & 33.9 & \\
& 81.0 & & & \\
\hline & & & & \\
& & & &
\end{tabular}

Source: Statistics Canada, Labour Force Survey.

part-time work, while the unemployment of young adults primarily involves those outside the educational system. In this sense, young adults are less like teenagers, but more like adults.

The previous discussion highlights various indicators that are relevant to the deteriorating youth situation in the 1990s. In this paper, we focus on the unemployment of youths relative to adults. We examine relative rates because youth unemployment rates have been persistently higher than adult unemployment rates, reflecting the job search of younger workers and the greater turnover associated with job matching. As well, given their lack of experience and seniority, youths are usually the "last-in, first-out," respectively during economic expansions and contractions. Yet, the relationship between youth and adult unemployment has changed remarkably over time, and it varies considerably by province and other factors. This begs the issue of whether a broader and deeper understanding of the factors associated with variation in the relationship between the youth and adult unemployment rates would provide clues as to the causal factors underlying that relationship. This paper involves a search for such clues. 
TABLE 2

Weeks of Unemployment by Educational Activity, Canada, 1994

Age Group

\begin{tabular}{|c|c|c|}
\hline Group & $16-19$ & $20-24$ \\
\hline & (1) & (2) \\
\hline \multicolumn{3}{|l|}{ Weeks Unemployed } \\
\hline Full-time students & $2,622,906$ & $2,086,769$ \\
\hline Part-time students ${ }^{1}$ & 517,382 & 921,710 \\
\hline Non-students & $1,895,940$ & $7,293,524$ \\
\hline Total & $5,036,228$ & $10,302,009$ \\
\hline \multicolumn{3}{|l|}{ Distribution of Weeks Unemployed } \\
\hline Full-time students (\% of total) & 52.1 & 20.3 \\
\hline Part-time students ${ }^{1}$ ( $\%$ of total) & 10.3 & 8.9 \\
\hline Non-students (\% of total) & 37.6 & 70.8 \\
\hline Total & 100.0 & 100.0 \\
\hline
\end{tabular}

Note: 'Includes students attending school both on a full- and part-time basis during year.

Source: Statistics Canada, Survey of Labour and Income Dynamics, 1994. Weighted to population using cross-sectional labour weight.

The stylized facts pertaining to the unemployment rate of youths relative to adults are first presented. This is followed by a portrayal of the time pattern for different groups, with regression analysis used to analyze its trend, cyclical pattern, and relationship to the size of the youth cohort. The paper concludes with a summary and suggestions for further research.

\section{Youth Unemployment Rates AND the DisTRIBUTION OF UNEMPLOYED}

As indicated in the last column of Table 3, the youth unemployment rate for both sexes at 15.2 percent is over twice the adult unemployment rate of 7 percent. The unemployment rate for teenagers (age $15-19)$ at 20 percent is particularly high, even when compared to the unemployment rate for young adults (age 20-24) at 12.3 percent. For both teenagers and young adults, the unemployment rates are higher for males than females. The unemployment rate for male teenagers at 21.5 percent is particularly striking, being over three times the rate for male or female adults. Although there is wide variation across countries, the Canadian pattern is similar to the average for Organization for Economic Cooperation and Development (OECD) countries (Bowers, Sonnet and Bardone 2000). Reflecting their high unemployment rates, youths constitute a disproportionate amount of the unemployed. As the first three columns of Table 3 illustrate, while youths constitute only 16.7 percent of the population and 15.9 percent of the labour force, they constitute 29 percent of the unemployed.

Table 4 suggests that when the adult rates are high (low), the youth rates are also high (low), although there is some variation in that pattern as exhibited by the ratio of youth to adult unemployment rates of column 3. For example, the highest unemploy- 
TABLE 3

Distribution and Incidence of Unemployment by Age and Sex, Canada 1998

\begin{tabular}{|c|c|c|c|c|c|}
\hline \multirow[b]{2}{*}{ Sex and Age Category } & \multicolumn{3}{|c|}{ Distribution } & \multicolumn{2}{|c|}{ Incidence (percentages) } \\
\hline & Population & Labour Force & Unemployed & Participation Rate & Unemployment Rate \\
\hline & (1) & (2) & (3) & (4) & (5) \\
\hline \multicolumn{6}{|l|}{ Both Sexes } \\
\hline Age $15-24$ & 0.167 & 0.159 & 0.290 & 62.0 & 15.2 \\
\hline Age 15-19 & 0.084 & 0.062 & 0.147 & 48.1 & 20.0 \\
\hline Age 20-24 & 0.083 & 0.097 & 0.142 & 76.0 & 12.3 \\
\hline Age 25+ & 0.833 & 0.841 & 0.710 & 65.8 & 7.0 \\
\hline \multicolumn{6}{|l|}{ Males } \\
\hline Age 15-24 & 0.085 & 0.083 & 0.165 & 63.6 & 16.6 \\
\hline Age $15-19$ & 0.043 & 0.032 & 0.082 & 48.3 & 21.5 \\
\hline Age 20-24 & 0.042 & 0.051 & 0.083 & 79.0 & 13.6 \\
\hline Age 25+ & 0.406 & 0.463 & 0.393 & 74.3 & 7.1 \\
\hline \multicolumn{6}{|l|}{ Females } \\
\hline Age 15-24 & 0.082 & 0.076 & 0.125 & 60.4 & 13.7 \\
\hline Age 15-19 & 0.041 & 0.030 & 0.066 & 47.9 & 18.4 \\
\hline Age $20-24$ & 0.041 & 0.046 & 0.059 & 72.9 & 10.7 \\
\hline Age $25+$ & 0.427 & 0.378 & 0.318 & 57.7 & 7.0 \\
\hline
\end{tabular}

Source: Statistics Canada, Labour Force Survey.

ment rates for both youths and adults, respectively at 28.6 percent and 16.1 percent, are in Newfoundland, yet that province has one of the lowest ratios of youth to adult unemployment at 1.8. That pattern generally prevails; that is, provinces with the highest rates of youth and adult unemployment (most Atlantic provinces and Quebec) tend to have the lowest ratios. This suggests that the factors that give rise to higher unemployment rates in general do not have a disproportionate effect on youth unemployment.

For both males and females, and for youths and adults, the unemployment rates are higher for single persons than for married persons. There are no major differences in youth unemployment rates according to student status. For all groups, unemployment rates are dramatically higher for those with lower levels of education, although the effect is more dramatic for youths compared to adults. As a result, the ratio of youth to adult unemployment also generally falls with higher levels of education. While education is important for adults, its effect becomes diluted by other factors such as general labour market experience and company-specific seniority. Youths have generally not yet been able to acquire those other attributes, and hence education is one of the few signals or productive inputs they possess. The benefits of the education advantage that youths traditionally have had over adults are dissipating over time, however, since there has been some convergence of youth and adult education levels. In that vein, youths may be losing their traditional educational advantage that helped offset their experience deficit (Kapsalis, Morissette and Picot 1999). 
TABLE 4

Unemployment Rates by Province, Marital Status and Education, Canada, 1998

\begin{tabular}{|c|c|c|c|c|}
\hline \multirow[b]{2}{*}{ Group } & \multicolumn{2}{|c|}{ Age Group } & \multirow{2}{*}{$\begin{array}{c}\text { Ratio } \\
(15-24) / 25+\end{array}$} & \multirow{2}{*}{$\begin{array}{c}\text { Difference } \\
(15-24)-25+\end{array}$} \\
\hline & $15-24$ & $25+$ & & \\
\hline & (1) & (2) & (3) & (4) \\
\hline Canada & 15.2 & 7.0 & 2.2 & 8.2 \\
\hline \multicolumn{5}{|l|}{ Province } \\
\hline Newfoundland & 28.6 & 16.1 & 1.8 & 12.5 \\
\hline Prince Edward Island & 16.4 & 13.3 & 1.2 & 3.1 \\
\hline Nova Scotia & 19.4 & 9.0 & 2.2 & 10.4 \\
\hline New Brunswick & 18.4 & 10.9 & 1.7 & 7.5 \\
\hline Quebec & 17.2 & 9.2 & 1.9 & 8.0 \\
\hline Ontario & 14.6 & 5.9 & 2.5 & 8.7 \\
\hline Manitoba & 10.6 & 4.6 & 2.3 & 6.0 \\
\hline Saskatchewan & 11.0 & 4.8 & 2.3 & 6.2 \\
\hline Alberta & 10.6 & 4.6 & 2.3 & 6.0 \\
\hline British Columbia & 17.3 & 7.4 & 2.3 & 9.9 \\
\hline \multicolumn{5}{|l|}{ Marital Status } \\
\hline \multirow{2}{*}{$\begin{array}{ll}\text { Males: } & \text { Single } \\
& \text { Married }\end{array}$} & 17.3 & 11.6 & 1.5 & 5.7 \\
\hline & 11.1 & 5.5 & 2.0 & 5.6 \\
\hline \multirow{2}{*}{$\begin{aligned} \text { Females: } & \text { Single } \\
& \text { Married }\end{aligned}$} & 14.3 & 8.9 & 1.6 & 5.4 \\
\hline & 11.2 & 6.1 & 1.8 & 5.1 \\
\hline \multicolumn{5}{|l|}{ Educational Attainment } \\
\hline 0 - 8 years & 26.3 & 12.9 & 2.0 & 13.4 \\
\hline Some high school & 22.4 & 11.2 & 2.0 & 11.2 \\
\hline High-school graduate & 13.9 & 7.1 & 1.9 & 6.8 \\
\hline Some postsecondary & 12.7 & 8.0 & 1.6 & 4.7 \\
\hline Postsec. certificate/diploma & 9.3 & 6.3 & 1.5 & 3.0 \\
\hline University degree & 8.9 & 4.1 & 2.2 & 4.8 \\
\hline \multicolumn{5}{|l|}{ Student Status ${ }^{1}$} \\
\hline Full-time student & 15.2 & 7.2 & 2.1 & 8.0 \\
\hline Part-time student & 13.4 & 7.2 & 1.9 & 6.2 \\
\hline Non-student & 15.3 & 7.2 & 2.1 & 8.1 \\
\hline
\end{tabular}

Note: ${ }^{1}$ Note, uses eight-month (January-April, September-December) averages.

Source: Statistics Canada, Labour Force Survey.

Table 5 highlights that youths are constituting a smaller share of unemployment over time, falling from 48.2 percent of the unemployed (27.4 percent for males and 20.8 percent for females) in 1976, to 29 percent (16.5 percent for males and 12.5 percent for females) by 1998. Their smaller share of the unemployed, however, largely reflects the fact that youths are now a much smaller share of the labour force. Between 1976 and 1998, the youth share of the labour force fell from 27.4 percent to 15.9 
TABLE 5

Youth Unemployment Rates and Percentages of Labour Force and Unemployed, Canada, 1976-1998

\begin{tabular}{|c|c|c|c|c|c|c|}
\hline \multirow[b]{2}{*}{ Year } & \multicolumn{3}{|c|}{ Males 15-24 } & \multicolumn{3}{|c|}{ Females 15-24 } \\
\hline & $\begin{array}{l}\text { Unempl. } \\
\text { Rate }\end{array}$ & $\begin{array}{c}\% \text { of Labour } \\
\text { Force }\end{array}$ & $\begin{array}{c}\% \text { of } \\
\text { Unemployed }\end{array}$ & $\begin{array}{l}\text { Unempl. } \\
\text { Rate }\end{array}$ & $\begin{array}{c}\% \text { of Labour } \\
\text { Force }\end{array}$ & $\begin{array}{c}\% \text { of } \\
\text { Unemployed }\end{array}$ \\
\hline & (1) & (2) & (3) & (4) & (5) & (6) \\
\hline 1976 & 13.1 & 0.150 & 0.274 & 12.0 & 0.124 & 0.208 \\
\hline 1977 & 14.8 & 0.149 & 0.271 & 13.7 & 0.124 & 0.209 \\
\hline 1978 & 14.9 & 0.147 & 0.261 & 13.8 & 0.123 & 0.203 \\
\hline 1979 & 13.1 & 0.147 & 0.258 & 12.6 & 0.125 & 0.209 \\
\hline 1980 & 13.6 & 0.145 & 0.263 & 12.5 & 0.125 & 0.208 \\
\hline 1981 & 13.9 & 0.142 & 0.262 & 12.1 & 0.123 & 0.196 \\
\hline 1982 & 20.9 & 0.135 & 0.256 & 15.9 & 0.118 & 0.172 \\
\hline 1983 & 22.2 & 0.130 & 0.242 & 16.8 & 0.115 & 0.163 \\
\hline 1984 & 19.2 & 0.127 & 0.216 & 16.0 & 0.112 & 0.159 \\
\hline 1985 & 18.0 & 0.122 & 0.210 & 14.4 & 0.109 & 0.149 \\
\hline 1986 & 16.3 & 0.120 & 0.204 & 13.5 & 0.107 & 0.150 \\
\hline 1987 & 14.6 & 0.115 & 0.190 & 12.3 & 0.102 & 0.143 \\
\hline 1988 & 12.8 & 0.110 & 0.180 & 10.9 & 0.098 & 0.138 \\
\hline 1989 & 12.3 & 0.106 & 0.172 & 10.0 & 0.095 & 0.125 \\
\hline 1990 & 13.9 & 0.100 & 0.170 & 11.3 & 0.091 & 0.127 \\
\hline 1991 & 18.8 & 0.095 & 0.173 & 13.3 & 0.088 & 0.113 \\
\hline 1992 & 20.2 & 0.092 & 0.164 & 15.1 & 0.085 & 0.113 \\
\hline 1993 & 20.2 & 0.089 & 0.160 & 14.9 & 0.081 & 0.108 \\
\hline 1994 & 18.5 & 0.088 & 0.157 & 14.3 & 0.079 & 0.110 \\
\hline 1995 & 17.0 & 0.086 & 0.153 & 14.0 & 0.079 & 0.116 \\
\hline 1996 & 17.5 & 0.084 & 0.152 & 14.6 & 0.076 & 0.115 \\
\hline 1997 & 17.6 & 0.083 & 0.159 & 15.7 & 0.075 & 0.128 \\
\hline 1998 & 16.6 & 0.083 & 0.165 & 13.7 & 0.076 & 0.125 \\
\hline
\end{tabular}

Source: Statistics Canada, Labour Force Survey.

percent for both sexes. In essence, this demographic fact of a declining share of the labour force accounts for much of the decline in the youth share of unemployment. As indicated in columns 1 and 4 of Table 5, youth unemployment rates, while fluctuating, also trended upwards, especially for male youths. Of course, the unemployment rate of adults (not shown in that table) also fluctuated and trended upwards over that period, raising the issue of who fared worse over time.

\section{Ratio of Youth/Adult Unemployment RATES OVER TIME}

Figure 1 portrays who fared worse over time. As indicated in Figure 1A, a u-shaped pattern prevails in the ratio of youth to adult unemployment rates, mainly for teenagers. Three distinct periods are evident. From 1976 to 1983 the ratio of youth-adult unemployment generally fell, rising as the economy moved into the severe recession of the early 1980s. 
FIGURE 1

Ratio of Youth-Adult Unemployment Rates, Canada, 1976-1998

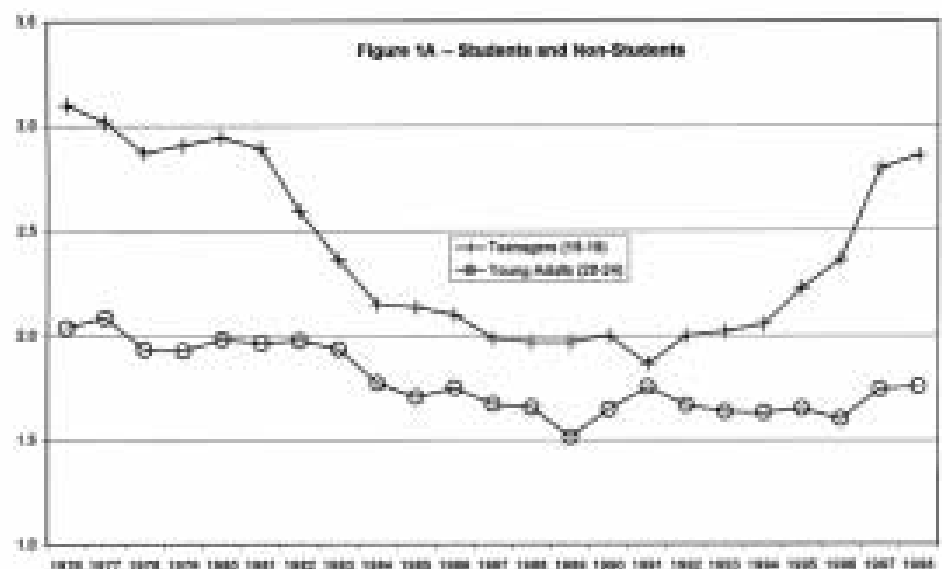

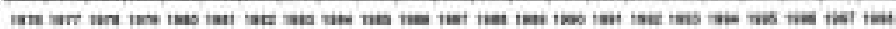
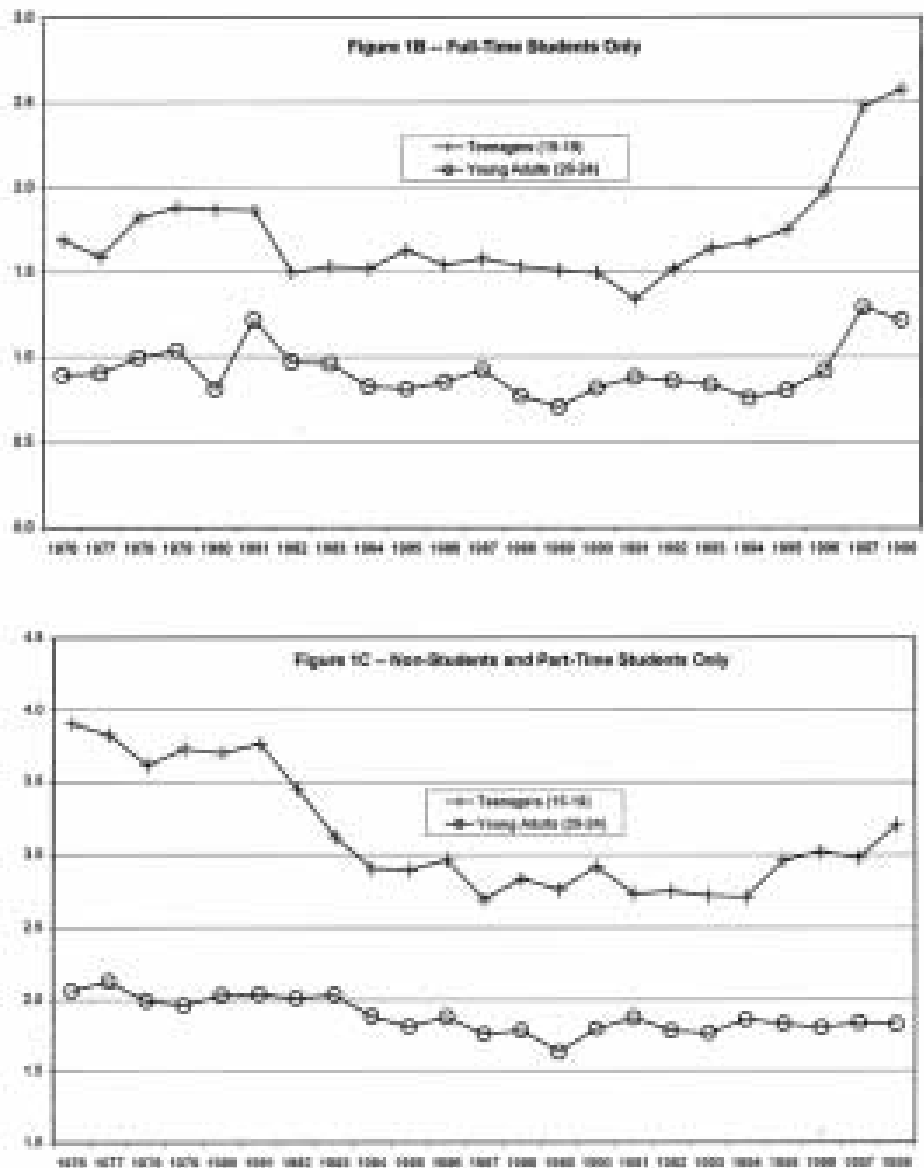

Canadian Public Policy - Analyse de Politiques, vol. Xxvi supplement/numéro spécial 12000 
The improvement in their relative position (a fall in the ratio) was particularly pronounced for teenagers, as was the deterioration in their position (a rise in the ratio) during the recession. From 1984 to 1990, the ratio of youth to adult unemployment remained low and fairly stable at a ratio of around 1.8, slightly higher for teenagers and lower for young adults. This improved position for youths occurred during a period of sustained expansion as the economy came out of the recession of the early 1980s. From 1991 to 1998 the relative position of youths again deteriorated as the ratio of youth to adult unemployment rose. Of note, however, this dramatic deterioration occurred only for teenagers and not for young adults. The increase for teenagers coincided with the recession of the early 1990s, increasing from a ratio of 1.9 in 1991 to almost 3 by 1998. It is this rapid deterioration in the unemployment position of teenagers in the 1990s that has attracted the increased attention in policy circles and the media. The deterioration is particularly noticeable after the sustained improvement in the late 1970s and early 1980s, and the levelling-off throughout the remainder of the 1980s. The u-shaped relationship also highlights that the issue of youth unemployment has not disappeared, although a portrayal of the period up to the early 1990s would have suggested that this was the case.

The $\mathrm{u}$-shaped relationship is also one where there is a "fanning-out" of the lines at the top of the $u$ and a convergence in the bottom of the $u$. That is, when the ratio of youth to adult unemployment is high, there is also greater disparity between the unemployment rate of teenagers 15-19 years compared to young adults 20-24 years. In essence, when youths are doing poorly relative to adults, that burden falls disproportionately on teenagers compared to young adults. Conversely, when youths are faring better relative to adults, teenagers benefit disproportionately relative to young adults. Not surprisingly, young adults are closer to adults than are teenagers in terms of their unemployment behaviour.

Although not portrayed in the figure, the general u-shaped pattern prevails for both males and fe- males, as does the higher ratio for teenagers relative to young adults. The ratio for males, however, is more volatile, especially for young adult males. The unemployment situation of young adult males is particularly and immediately sensitive to businesscycle fluctuations. Perhaps for that group a return to school is not as viable an alternative as it is for teenagers. As well, they may be less likely than teenagers (and perhaps young women) to become discouraged from looking for work and drop out of the labour market altogether.

When the youth full-time student population (Figure 1B) is separated from non-students and parttime students ${ }^{3}$ (Figure 1C) it is clear that relative deterioration that youth faced in the 1990s occurred mainly due to increasing relative unemployment rates of full-time students, especially for teenagers. For non-students (Figure 1C) the ratios of youth to adult unemployment rates have been fairly constant in recent years, although they rose slightly for teenagers after the recession of the early 1990s. In fact, for non-students the ratios have been fairly constant since the recession of the early 1980s, being higher for teenagers (15-19) than for young adults (20-24).

\section{Time-SERIES REgResSIONS}

In order to provide a more parsimonious description of the relationship between the youth and adult unemployment rates, a number of time-series regressions were run. The specification essentially involved regressing the ratio of youth to adult unemployment rates on a quadratic time trend (to reflect the generally u-shaped relationship discussed previously), a business-cycle measure ${ }^{4}$ and a demographic cohort size variable that measures the proportion of youths in the population. The demographic variable was included to see if the reduced competitive pressures associated with a declining proportion of youths in the population (as outlined previously) would be associated with reductions in the unemployment rate of youths relative to adults. 
Because the coefficients on the quadratic time and time-squared terms would not provide direct information on the trends, the average annual trends were calculated over three sub-periods, corresponding to the declining, flat, and upward portion of the " $u$ " as exhibited in Figure 1A. The three sub-periods of approximately equal length were: 1976-1983 when the ratio of youth to adult unemployment rates were generally declining; 1984-1990 when the ratio was generally constant; and 1991-1998 when the ratio again began to increase. Such trend measures will have filtered out the effect of the declining share of youth in the population as well as the business cycle. The trend measures are simply the derivative of the ratio with respect to time ${ }^{5}$ evaluated at each year and averaged over each of the three periods.

The equations are estimated separately for males and females, teenagers and young adults, and nonstudents and full-time students so that the effects of the youth cohort size, the business cycle, and the trend are allowed to vary across the different groups. The equations are estimated as a system of equations using seemingly unrelated regressions (SUR) as is appropriate when they have a common set of explanatory variables with values differing across the groups (as is the case with the youth share of the population). ${ }^{6}$

\section{Demographic Effect of Declining Share of Youths in the Population}

The top panel of Table 6 indicates the results for students and non-student youths combined. As indicated in column 2 , the demographic variable (share of youths in the population) has a large effect in the expected direction. That is, as the youth share of the population increases so does the ratio of youth to adult unemployment. Conversely, as the youth share declines (as has been the case over this period) the ratio drops.

The magnitudes of the effects are substantial. For example, the share of youths 15-24 years in the population fell by 10.02 (i.e., from 26.69 to 16.67 percent of the population) between 1976 and 1998 . This would be associated with a drop in the ratio of youth to adult unemployment rates of 1.16 (i.e., $10.02 \times$ coefficient of 0.116 from the first row) over that period. This is a substantial magnitude relative to the mean ratio of 2.02 for youths relative to adults. Alternatively stated, if the youth share of the population had remained at its 1976 level of 26.69 percent instead of dropping to 16.67 percent by 1998 , the ratio of youth to adult unemployment in 1998 would have been 1.16 higher (i.e., adding back the effect of the demographic change that otherwise reduced the ratio) for a ratio of 3.36 instead of its actual ratio of 2.20. In essence, the demographic "gift" from the declining youth share of the labour force contributed significantly to the reduction of the ratio over that period; without the demographic effect the ratio would have been 3.36 which is higher than the ratio in any year over that period.

Separate calculations for males and females indicate that if the youth share of the population force had remained at its 1976 level, the ratio of youth to adult unemployment in 1998 would have been 0.95 higher for males (i.e., a ratio of 3.31 instead of its actual ratio of 2.37) and 1.38 higher for females (i.e., a ratio of 3.34 instead of 1.96).

These calculations highlight that the slight improvement in the ratio of youth to adult unemployment which tended to occur over the 1976-98 period for both males and females can be attributed entirely (in fact, more than entirely) to the demographic gift associated with the declining share of youths in the labour force. In fact, without that gift the ratio would have risen dramatically as a result of the underlying forces at work that are simply being reflected here by the business cycle and trend. This should give pause to the notion that the youth labour market has improved since the mid-1970s as evidenced by the (slightly) declining ratio of youth to adult unemployment. This has occurred, but any improvement appears due entirely to the demographic gift of a smaller proportion of youth in the labour market. If this had not occurred, the other underlying forces in the youth labour market would have led to a dramatic deterioration in the 
TABLE 6

Correlates of Ratio of Youth 15-24/ Adult 25+ Unemployment Rates, by Student Activity, Sex and Age, Canada, 1976-1998, Based on SUR Estimates

\begin{tabular}{|c|c|c|c|c|c|c|}
\hline & \multirow[b]{2}{*}{ Mean Ratio } & \multirow[b]{2}{*}{ Youth Pop. Share } & \multirow[b]{2}{*}{ Cycle } & \multicolumn{3}{|c|}{ Average Annual Trend (dy/dt) } \\
\hline & & & & $1976-83$ & $1984-90$ & $1991-98$ \\
\hline & (1) & (2) & (3) & (4) & (5) & (6) \\
\hline Total & 2.02 & 0.116 & -0.001 & -0.012 & 0.038 & 0.087 \\
\hline Male 15-24 & 2.19 & 0.190 & -0.019 & -0.006 & 0.031 & 0.067 \\
\hline Male 15-19 & 2.57 & 0.803 & 0.004 & 0.050 & 0.083 & 0.115 \\
\hline Male 20-24 & 1.95 & -0.042 & -0.039 & -0.016 & -0.020 & -0.024 \\
\hline Female 15-24 & 1.83 & 0.273 & 0.020 & -0.021 & 0.044 & 0.109 \\
\hline Female 15-19 & 2.21 & 0.776 & 0.021 & 0.014 & 0.071 & 0.128 \\
\hline Female 20-24 & 1.59 & 0.135 & 0.012 & -0.052 & -0.006 & 0.039 \\
\hline \multicolumn{7}{|c|}{ Non- and Part-Time Students } \\
\hline Male 15-24 & 2.40 & 0.071 & -0.027 & -0.021 & -0.005 & 0.010 \\
\hline Male 15-19 & 3.38 & 0.775 & -0.002 & 0.065 & 0.059 & 0.053 \\
\hline Male 20-24 & 2.11 & -0.005 & -0.037 & 0.002 & -0.010 & -0.021 \\
\hline Female 15-24 & 1.91 & 0.190 & 0.015 & -0.033 & 0.019 & 0.072 \\
\hline Female 15-19 & 2.84 & 0.654 & 0.022 & 0.006 & 0.045 & 0.085 \\
\hline Female 20-24 & 1.64 & 0.204 & 0.011 & -0.037 & 0.009 & 0.056 \\
\hline \multicolumn{7}{|l|}{ Full-Time Students } \\
\hline Male 15-24 & 1.68 & 0.460 & 0.040 & 0.080 & 0.136 & 0.191 \\
\hline Male 15-19 & 1.88 & 0.836 & 0.042 & 0.129 & 0.138 & 0.147 \\
\hline Male 20-24 & 1.02 & 0.130 & 0.004 & -0.018 & 0.028 & 0.074 \\
\hline Female 15-24 & 1.37 & 0.423 & 0.026 & 0.071 & 0.112 & 0.153 \\
\hline Female 15-19 & 1.54 & 0.567 & 0.022 & 0.058 & 0.087 & 0.116 \\
\hline Female 20-24 & 0.78 & 0.288 & -0.005 & 0.013 & 0.038 & 0.063 \\
\hline
\end{tabular}

Notes: Cycle is calculated as percentage deviation from trend in real gross domestic product. Where youth are disaggregated by student activity, the dependent variable is a ratio of unemployment rates averaged over an eightmonth period (January-April, September-December).

Source: Calculations as described in text based on the regression results of Table A1 in appendix. The original data are from Statistics Canada, Labour Force Survey and National Accounts Data (Cansim Matrix 6549)

unemployment of youths relative to adults. Furthermore, as indicated previously, the actual unemployment rates of youths over that period have increased substantially, as have the rates for adults. As well, the reduction of the ratio of youth to adult unemployment rates that was occurring over the 1970 s and 1980s appears to have reversed itself in the 1990s. For these reasons, we cannot be sanguine about the youth unemployment issue.

The separate figures for teenagers (15-19) and young adults (20-24) highlight clearly that the demographic effect is much larger for teenagers than for young adults. That is, teenagers much more than 
young adults have benefited by the reduced competition for jobs that is associated with the smaller proportions of youths in the labour market

The separate results for non-students (middle panel) and full-time students (bottom panel) indicate that the demographic gift had a positive impact on the relative unemployment of all youth groups. The exception is young adult (20-24) non-student males, albeit their negative coefficient is statistically insignificant $(\mathrm{t}=-0.08)$ and quantitatively small. That group is more like adults in the sense that their unemployment rate relative to adults has not been substantially affected by the demographic gift associated with youths being a smaller share of the labour force. They appear not to have benefited by the reduced competition amongst youths for jobs.

\section{Business Cycle}

Somewhat surprisingly, after filtering out the demographic effect and the trend, the business cycle does not have a consistent effect whereby expansions reduce the ratio of youth to adult unemployment rates across the different groups (i.e., negative coefficients). The coefficient of -0.001 for the cycle variable for all youths (top row of Table 6) is of the expected sign, but it is quantitatively minuscule and statistically insignificant $(\mathrm{t}=-0.16)$.

For particular subgroups, however, the businesscycle effects are more substantial, especially when cumulated over a full cyclical contraction. For example, for male youths (15-24) the negative and statistically significant $(t=-2.83)$ coefficient does indicate that they benefit by cyclical expansions which lower their unemployment rate relative to that of adults. The coefficient of approximately -0.02 indicates that a one-unit increase in the percentage deviation of gross domestic product (GDP) from trend (i.e., approximately the value in 1991) is associated with a 0.02 reduction in the ratio of male youth to adult unemployment rates. While this is a small reduction relative to the mean of slightly over 2.00 , it is more substantial when cumulated over the life of a recession. For example, the cumulative negative deviation of GDP from trend over the 1981 and 1982 recession was 8.4, which implies an increase in the ratio of male youth to adult unemployment rates of 0.16 (i.e., -8.4 x -0.019). Each year from 1991 to 1998 had a negative deviation of GDP from trend (with a cumulative value of 11.3) highlighting the prolonged legacy of the 199293 recession (with each of those two years having an almost 3 percent negative deviation from trend). The cumulative negative deviation of GDP from trend over the period 1991 to 1998 would imply an increase in the ratio of male youth to adult unemployment rates of 0.21 (i.e., $-11.3 \times-0.019$ ).

The separate coefficients for males 15-19 and 2024 indicate that the negative effect of business-cycle contractions is confined exclusively to young adult males 20-24 years. The coefficient of -0.039 is double that of the coefficient for both age groups combined; hence, the cumulative effects are double those discussed in the previous paragraph.

The separate coefficient estimates for males in the bottom two panels indicate that the businesscycle effects are different for non-students and full-time students. The impact of business-cycle expansion on reducing the ratio of youth to adult unemployment rates for young adult males is entirely the result of the effect on non-students (coefficient of -0.037). ${ }^{7}$ For young adult (20-24) males who are full-time students, the business-cycle effect is quantitatively small and statistically insignificant (coefficient of $0.004, t=0.30$ ).

For teenage males who are full-time students, an expansion has the "perverse" effect of increasing the ratio of their unemployment relative to that of adults (coefficient of $0.040, t=5.15$ ). Presumably, for this group a cyclical expansion induces them to look for work (in which case they would be recorded as unemployed) even though they are full-time students.

For most groups of female youths a businesscycle expansion tends to increase the ratio of their 
unemployment relative to adult unemployment as evidenced by their positive coefficients. The effects are generally small, however, as evidenced by the coefficients typically being around 0.02 . Apparently a business-cycle expansion tends to induce many female youths to look for work, in which case they would be recorded as unemployed.

Overall, expansions tend to reduce the ratio of youth to adult unemployment for male young adults (20-24) who are non-students or part-time students, and they increase the ratio for male teenagers (1519) who are full-time students, and have no effect for other male youths. For female youths, expansions tend to increase their unemployment relative to adults. In essence, with the exception of young adult males, cyclical expansions tend to either have no substantial effect on the ratio of youth to adult unemployment, or they actually increase that ratio, presumably because the improved economic condition induces them to look for work and hence be recorded as unemployed.

\section{Trend}

The pronounced $\mathrm{u}$-shaped trend that is apparent in the previous figures remains after using regression to filter out the effect of the business cycle and the declining share of youths in the population. ${ }^{8}$ As the top row indicates, for male and female youths the first period, 1976-83, is characterized by a declining ratio of youth to adult unemployment, followed by a slight upward rising middle period, 1984-90, followed by a rapidly rising ratio in the third period, 1991-98.

The disaggregate separate figures for teenagers and young adults, however, reveal that this pattern did not prevail across those age groups. For male and female teenagers, the trend was upward and higher in each successive period. For young adult males there was a negative average annual decline of around -0.02 over each of the periods, and only young adult females had the u-shaped relationship.

A similar trend relationship tends to prevail in the separate regressions for non-students (middle panel) and full-time students (bottom panel). That is, the trend is upwards in each successive period for male and female teenagers whether non-students or full-time students. For young adults (20-24) it is fairly flat for male non-students, $\mathrm{u}$-shaped for female non-students and full-time students, and rising for female full-time students. Of particular note, the trend during the 1991-98 period was upwards for all groups except young adult, non-student males.

\section{Summary AND Discussion}

Currently, youth unemployment rates are slightly over twice the adult rate, with the unemployment rate of male teenagers at 21.5 percent being over three times the adult rate of 7 percent. Although they constitute only about 16 percent of the population and the labour force, youths constitute almost onethird (29 percent) of the unemployed.

The ratio of youth-adult rates exhibits a u-shaped pattern, declining markedly from 1976 to 1983 , levelling-off from 1984 to 1990, but rising sharply thereafter, mainly for teenagers.

The u-shaped pattern is essentially produced by the combination of a relative improvement among non-students in the late 1970s and 1980s, and a relative deterioration in the position of full-time students seeking part-time work over the 1990s.

If it were not for the demographic gift of a declining cohort size, the ratio of youth to adult unemployment would have been substantially higher than its already high ratio in the 1990s.

Recessions tend to worsen the unemployment of youths relative to adults for non-student males while improving it for students.

The youth labour market is not homogeneous, but varies considerably between males and females, teenagers and young adults, and students and nonstudents. 
The analysis has highlighted a number of areas that merit further research. The deterioration in the relative unemployment position of full-time students looking for part-time work suggests that more attention be given to the meaning and implications of their unemployment. Research is needed to determine the underlying causes of the different and changing patterns uncovered in this analysis - that is, to determine what lies behind the underlying trends and cyclical patterns. In particular, research is needed to determine the relative importance of such factors as shifts in the incidence and duration of unemployment, employment insurance reforms, minimum wages, payroll taxes, self-employment, industry shifts from manufacturing to services, converging education patterns between adults and youths, global competition, technological change and non-labour market alternatives such as early retirement for adults and schooling for youths. For example, could the decline in the real minimum wage have contributed to some of the decline in youth unemployment relative to adult unemployment in the earlier period? Could the growth of self-employment (increasingly common among adults but not among youths) have contributed more to reducing adult unemployment than youth unemployment in recent years? Could the industrial restructuring from manufacturing to services (the later disproportionately employing youths and being less sensitive to cyclical fluctuations) have reduced youth unemployment and made it less sensitive to cyclical fluctuations? Could the recent increases in tuition have caused many students to look for parttime work to finance their education? Clearly, further research is needed to uncover the underlying factors that contribute to the time pattern of youth unemployment documented in this analysis.

\section{Notes}

Earlier versions of this paper were given at the Centre for the Study of Living Standards Conference on Structural Aspects of Unemployment, Ottawa, 22-23 April 1999 and the Canadian Economics Association Meetings, Toronto, 28 May 1999. Without implicating them for any of the conclusions, the authors are indebted to David Foot, Rafael Gomez, Gilles Grenier, Graham Lowe and René Morissette and two anonymous referees for helpful comments and discussions.

${ }^{1}$ Justus and McCracken (1997) note that between 1991 and 1997, tuition fees had risen 56 percent on average, whereas the overall rise in CPI was only 6 percent. This contributed to rising debt loads of graduates from $\$ 8,700$ in 1990 , to $\$ 17,000$ in 1996 . For data on tuition fees, see Statistics Canada (1999b).

${ }^{2}$ In Canada, full-time students looking for full-time (as opposed to part-time) work are recorded as out of the labour force rather than unemployed since they are assumed to be not available for such work given their full-time student status. This is in contrast to the United States where such persons are recorded as unemployed. As indicated in Statistics Canada (1998), this procedure lowers the Canadian overall and youth unemployment rates respectively by 0.3 and 0.9 of a percentage point relative to what it would be if the US procedures were followed. Furthermore, full-time work in the United States is defined as 35 hours or more per week compared to 30 hours or more in Canada.

3In the text, the phrase "non-student" is often used to refer to non-students and part-time students combined.

${ }^{4}$ The percent deviation of real gross domestic product from its trend, as used in Gunderson (1981), is preferable to any measure involving unemployment rates since the adult unemployment rate is also in the denominator of the dependent variable. The cycle values for Canada (with the last two digits of the year in parenthesis) are: -2.284 (76), -1.380 (77), 0.120(78), 1.741(79), 0.617(80), $1.120(81),-4.359(82),-4.141(83)-1.121(84), 1.641(85)$, 1.748(86), 3.270(87), 5.520(88), 5.526(89), 3.296(90), $-1.093(91),-2.686(92),-2.913(93),-0.794(94)$, $-0.711(95),-2.011(96),-0.775(97),-0.331(98)$. The depth of the 1982-83 recession and the lingering effect of the 1991-93 recession are apparent.

${ }^{5}$ Based on the regression $y=\alpha+\beta \mathrm{T}+\phi \mathrm{T}^{2}+\gamma($ cycle $)+\ldots$ controls, and where $y$ is the ratio of youth to adult unemployment rates, $\mathrm{T}$ is time coded as the last two digits of the years 1976 to 1998 , then $\delta \gamma / \delta \mathrm{T}=\beta+2 \phi \mathrm{T}$. These are evaluated for each year $\mathrm{T}$ and averaged over the three subperiods. The inflection point occurs where the rate of change or derivative is zero; that is, where $\delta \gamma / \delta \mathrm{T}=0$ or $\beta+2 \phi \mathrm{T}=0$ or $\mathrm{T}=-\beta / 2 \phi$. The inflection point is a 
minimum if the first derivative is negative (i.e., $\delta \gamma / \delta \tau<0$ ) and the second derivative is positive (i.e., $\delta^{2} / \delta \mathrm{T}^{2}>0$ ).

${ }^{6}$ The results are similar to those based on conventional OLS estimates (available upon request).

${ }^{7}$ It is possible that the general insensitivity of the youth-adult unemployment rate to business-cycle fluctuations reflects the disproportionate employment of youths to the service sector which is less sensitive to cyclical fluctuations. This could also be a reason for the stronger cyclical effect for non-student males age 20-24, who are less likely to be employed in those cyclically insensitive industries.

${ }^{8}$ As discussed previously, the trend is portrayed as the average annual change in the ratio over the three time intervals corresponding to the different segments of the u-shaped pattern portrayed in the earlier figures. It is the derivative of the ratio with respect to time, evaluated at each year, and averaged over each time interval.

\section{REFERENCES}

Archambault, R. and L. Grignon. 1999. "Decline in the Youth Participation Rate since 1990: Structural or Cyclical?" Working Paper No. W-99-1E. Ottawa: Applied Research Branch, Human Resources Development Canada.

Betcherman, G. and N. Leckie. 1997. "Youth Employment and Education: Trends in the 1980s and 1990s," Working Paper No. W03. Ottawa: Canadian Policy Research Networks

Bowers, N., A. Sonnet and L. Bardone. 2000. "Giving Young People a Good Start: The Experience of OECD Countries," Background Paper. Paris: Organization for Economic Cooperation and Development.

Foot, D. 1997. "Youth Unemployment: A 'Bust' Priority," The Globe and Mail, 14 October.

Gunderson, M. 1981. Unemployment among Young People and Government Policy in Ontario. Toronto: Ontario Economic Council.

Jennings, P. 1998. "School Enrolment and the Declining Youth Participation Rate," Working Paper No. R-984E. Ottawa: Applied Research Branch, Human
Resources Development Canada.

Justus, M. and M. McCracken. 1997. "Securing the Future of Canadian Youth: A Review of the Landscape," Monthly Economic Review 16(6):1-16.

Kapsalis, C., R. Morissette and G. Picot. 1999. The Returns to Education, and the Increasing Wage Gap Between Younger and Older Workers, Research Paper No. 131. Ottawa: Analytical Studies Branch, Statistics Canada.

Lavoie, C. and A. Béjaoui. 1998. "Youth Employment Situation in Canada: Explanations and Future Outlook," Working Paper No. R-98-10E. Ottawa: Applied Research Branch, Human Resources Development Canada.

Marquardt, R. 1996. "Youth and Work in Troubled Times: A Report on Canada in the 1990s," Working Paper No. W01. Ottawa: Canadian Policy Research Networks. Meunier, D., P. Bernard and J. Boisjoly. 1998. "Eternal Youth? Changes in the Living Arrangements of Young People," in Labour Markets, Social Institutions, and the Future of Canada's Children, ed. M. Corak. Ottawa: Statistics Canada and Human Resources Development Canada.

Morissette, R. 1998. "The Declining Labour Market Status of Young Men," in Labour Markets, Social Institutions, and the Future of Canada's Children, ed. M. Corak. Ottawa: Statistics Canada and Human Resources Development Canada.

Picot, G. 1998. What is Happening to Earnings Inequality and Youth Wages in the 1990s? Research Paper No. 116. Ottawa: Analytical Studies Branch, Statistics Canada.

Picot, G. and A. Heisz. 1999. "The 1990s Labour Market." Ottawa: Statistics Canada, unpublished paper.

Statistics Canada. 1998. Labour Force Update: CanadaUS Labour Market Comparisons, Cat. No. 71-005-XPB. Ottawa: Supply and Services Canada. 1999a. "Young Adults Living at Home, 1996," The Daily, 11 March.

1999b. "University Tuition Fees," The Daily, 25 August.

Wilkins, C. 1998. "Youth and the 1990s Labour Market," Working Paper No. 98-08. Ottawa: Department of Finance. 
TABLE A1

Regression Results of SUR Estimations

\begin{tabular}{|c|c|c|c|c|c|c|c|}
\hline & Constant & Youth Pop Share & Cycle & Time & $\operatorname{Time}^{2}$ & $R^{2}$ & Durbain Watson \\
\hline \multicolumn{8}{|c|}{ Total: Non-Students, Part-Time Students and Full-Time Students } \\
\hline B15-24 & $\begin{array}{r}21.051 \\
(4.92)\end{array}$ & $\begin{array}{l}0.116 \\
(4.56)\end{array}$ & $\begin{array}{l}-0.001 \\
(-0.16)\end{array}$ & $\begin{array}{l}-0.536 \\
(-6.54)\end{array}$ & $\begin{array}{r}0.003 \\
(7.62)\end{array}$ & 0.94 & 1.28 \\
\hline M15-24 & $\begin{array}{r}15.803 \\
(3.57)\end{array}$ & $\begin{array}{l}0.190 \\
(3.59)\end{array}$ & $\begin{array}{l}-0.019 \\
(-2.83)\end{array}$ & $\begin{array}{l}-0.393 \\
(-4.56)\end{array}$ & $\begin{array}{c}0.002 \\
(5.27)\end{array}$ & 0.89 & 1.02 \\
\hline M15-19 & $\begin{array}{l}7.404 \\
(0.60)\end{array}$ & $\begin{array}{l}0.803 \\
(4.82)\end{array}$ & $\begin{array}{l}0.004 \\
(0.43)\end{array}$ & $\begin{array}{l}-0.293 \\
(-1.20)\end{array}$ & $\begin{array}{l}0.002 \\
(1.67)\end{array}$ & 0.91 & 0.89 \\
\hline M20-24 & $\begin{array}{l}2.029 \\
(0.61)\end{array}$ & $\begin{array}{l}-0.042 \\
(-0.65)\end{array}$ & $\begin{array}{l}-0.039 \\
(-6.02)\end{array}$ & $\begin{array}{l}0.024 \\
(0.29)\end{array}$ & $\begin{array}{l}-0.000 \\
(-0.51)\end{array}$ & 0.76 & 1.70 \\
\hline F15-24 & $\begin{array}{r}27.641 \\
(7.39)\end{array}$ & $\begin{array}{r}0.273 \\
(6.18)\end{array}$ & $\begin{array}{l}0.020 \\
(4.01)\end{array}$ & $\begin{array}{r}-0.708 \\
(-10.00)\end{array}$ & $\begin{array}{r}0.004 \\
(11.70)\end{array}$ & 0.96 & 2.10 \\
\hline F15-19 & $\begin{array}{r}20.879 \\
(1.78)\end{array}$ & $\begin{array}{l}0.776 \\
(4.97)\end{array}$ & $\begin{array}{l}0.021 \\
(2.26)\end{array}$ & $\begin{array}{r}-.594 \\
(-2.53)\end{array}$ & $\begin{array}{l}0.004 \\
(3.08)\end{array}$ & 0.94 & 1.20 \\
\hline $\mathrm{F} 20-24$ & $\begin{array}{r}24.347 \\
(9.80)\end{array}$ & $\begin{array}{l}0.135 \\
(2.38)\end{array}$ & $\begin{array}{l}0.012 \\
(2.38)\end{array}$ & $\begin{array}{r}-.537 \\
(-8.81)\end{array}$ & $\begin{array}{l}0.003 \\
(8.29)\end{array}$ & 0.92 & 2.34 \\
\hline \multicolumn{8}{|c|}{ Non-Students and Part-Time Students } \\
\hline M15-24 & $\begin{array}{l}9.729 \\
(1.99)\end{array}$ & $\begin{array}{l}0.071 \\
(1.21)\end{array}$ & $\begin{array}{r}-0.027 \\
(3.71)\end{array}$ & $\begin{array}{l}-0.182 \\
(-1.91)\end{array}$ & $\begin{array}{l}0.001 \\
(1.99)\end{array}$ & 0.85 & 1.54 \\
\hline M15-19 & $\begin{array}{l}-8.678 \\
(-0.54)\end{array}$ & $\begin{array}{l}0.775 \\
(3.56)\end{array}$ & $\begin{array}{l}-0.002 \\
(-0.19)\end{array}$ & $\begin{array}{l}0.125 \\
(0.39)\end{array}$ & $\begin{array}{l}-0.000 \\
(-0.23)\end{array}$ & 0.87 & 1.69 \\
\hline M20-24 & $\begin{array}{l}-2.910 \\
(-0.91)\end{array}$ & $\begin{array}{l}-0.005 \\
(-0.08)\end{array}$ & $\begin{array}{l}-0.037 \\
(-5.97)\end{array}$ & $\begin{array}{l}0.126 \\
(1.61)\end{array}$ & $\begin{array}{l}-0.001 \\
(-1.66)\end{array}$ & 0.70 & 2.48 \\
\hline F15-24 & $\begin{array}{r}24.494 \\
(5.67)\end{array}$ & $\begin{array}{l}0.190 \\
(3.72)\end{array}$ & $\begin{array}{l}0.015 \\
(2.68)\end{array}$ & $\begin{array}{l}-0.588 \\
(-7.19)\end{array}$ & $\begin{array}{l}0.003 \\
(8.19)\end{array}$ & 0.94 & 2.05 \\
\hline F15-19 & $\begin{array}{r}15.386 \\
(1.82)\end{array}$ & $\begin{array}{l}0.654 \\
(5.90)\end{array}$ & $\begin{array}{l}0.022 \\
(3.14)\end{array}$ & $\begin{array}{l}-0.412 \\
(-2.42)\end{array}$ & $\begin{array}{l}0.003 \\
(2.91)\end{array}$ & 0.96 & 2.68 \\
\hline F20-24 & $\begin{array}{r}22.808 \\
(8.02)\end{array}$ & $\begin{array}{l}0.204 \\
(3.62)\end{array}$ & $\begin{array}{l}0.011 \\
(1.87)\end{array}$ & $\begin{array}{l}-0.525 \\
(-7.63)\end{array}$ & $\begin{array}{l}0.003 \\
(7.48)\end{array}$ & 0.84 & 2.31 \\
\hline \multicolumn{8}{|c|}{ Full-Time Students } \\
\hline M15-24 & $\begin{array}{r}12.808 \\
(2.43)\end{array}$ & $\begin{array}{l}0.460 \\
(7.33)\end{array}$ & $\begin{array}{l}0.040 \\
(5.15)\end{array}$ & $\begin{array}{l}-0.510 \\
(-4.98)\end{array}$ & $\begin{array}{l}0.004 \\
(6.78)\end{array}$ & 0.88 & 1.85 \\
\hline M15-19 & $\begin{array}{r}-10.018 \\
(-0.66)\end{array}$ & $\begin{array}{l}0.836 \\
(4.10)\end{array}$ & $\begin{array}{l}0.042 \\
(3.21)\end{array}$ & $\begin{array}{l}0.034 \\
(0.11)\end{array}$ & $\begin{array}{l}0.000 \\
(0.37)\end{array}$ & 0.79 & 0.90 \\
\hline M20-24 & $\begin{array}{r}20.852 \\
(2.88)\end{array}$ & $\begin{array}{l}0.130 \\
(0.91)\end{array}$ & $\begin{array}{l}0.004 \\
(0.30)\end{array}$ & $\begin{array}{l}-0.503 \\
(-2.82)\end{array}$ & $\begin{array}{l}0.003 \\
(2.84)\end{array}$ & 0.39 & 2.27 \\
\hline F15-24 & $\begin{array}{l}7.827 \\
(1.33)\end{array}$ & $\begin{array}{l}0.423 \\
(6.08)\end{array}$ & $\begin{array}{l}0.026 \\
(3.34)\end{array}$ & $\begin{array}{l}-0.365 \\
(-3.27)\end{array}$ & $\begin{array}{l}0.003 \\
(4.71)\end{array}$ & 0.84 & 1.85 \\
\hline F15-19 & $\begin{array}{l}5.629 \\
(0.37)\end{array}$ & $\begin{array}{l}0.567 \\
(2.83)\end{array}$ & $\begin{array}{l}0.022 \\
(1.85)\end{array}$ & $\begin{array}{r}-0.0248 \\
(-0.82)\end{array}$ & $\begin{array}{l}0.002 \\
(1.20)\end{array}$ & 0.74 & 0.96 \\
\hline F20-24 & $\begin{array}{l}8.603 \\
(1.20)\end{array}$ & $\begin{array}{l}0.288 \\
(3.04)\end{array}$ & $\begin{array}{l}-0.005 \\
(-0.54)\end{array}$ & $\begin{array}{l}-0.255 \\
(-2.43)\end{array}$ & $\begin{array}{l}0.002 \\
(2.66)\end{array}$ & 0.45 & 1.77 \\
\hline
\end{tabular}

Source: As described in Table 6. T-Statistics in parentheses. 